\title{
Impact of climate change on hydrology of Manjalar sub basin of river Vaigai in Tamil Nadu, India
}

\author{
S. Janapriya*1, S. Santhana Bosu ${ }^{2}$ and Balaji Kannan ${ }^{3}$ \\ ${ }^{*}$ Soil and Water Conservation Engineering, Vanavarayar Institute of Agriculture, Manakkadavu, Pollachi-642103 \\ (Tamil Nadu), INDIA \\ ${ }^{2 \& 3}$ Soil and Water Conservation Engineering, Tamil Nadu Agricultural University, Coimbatore -641003 (Tamil \\ Nadu), INDIA \\ *Corresponding author. E-mail: jans.priya@gmail.com
}

Received: January 13, 2016; Revised received: June 28, 2016; Accepted: August 27, 2016

\begin{abstract}
This study evaluates the impacts of possible future climate change scenarios on the hydrology of the catchment area of the Manjalar sub basin of River Vaigai, Tamil Nadu, India carried out at the department of Soil and Water Conservation Engineering, Tamil Nadu Agricultural University during the period of 2011-2014 using Soil and Water Assessment Tool (SWAT). For the climate impact assessment the hydrological model was driven with output of bias corrected Earth System Models of the Coupled Model Intercomparison Project Phase 5 (CMIP5): HadGEM2. Climate scenarios were downscaled to a grid resolution of $0.22^{\circ} \times 0.22^{\circ}$. In this study RCP 4.5 and RCP 8.5 were included for future assessment with three future periods: 2012-2039, 2040-2069, and 2070-2098. The projected increase in maximum and minimum temperature for RCP 4.5 scenario is 0.8 to $2.3{ }^{\circ} \mathrm{C}$ and 0.7 to $1.6 \stackrel{\circ}{\circ}$ and for RCP 8.5 scenario is 1.1 to $4.0^{\circ} \mathrm{C}$ and 1.0 to $3.1^{\circ} \mathrm{C}$, respectively. Rainfall is projected to an increase between 9.2 to 15.2 per cent for RCP 4.5 scenario and an increase of 13.6 to 18.8 per cent for RCP 8.5 scenario during $21^{\text {st }}$ century. The soil water storage and stream flow contribution to ground water are likely to increase in RCP 4.5 scenario and it would again decline for RCP 8.5 scenario during $21^{\text {st }}$ century. The increase in annual rainfall evapotranspiration and surface runoff would be more in RCP 8.5 scenario compared to RCP 4.5 scenario. The possible changes projected by the study provide a useful input to effective planning of water resources of the study area.
\end{abstract}

Keywords: Climate change impacts, Hydrologic model, RCP 4.5 and RCP 8.5 scenario, Surface runoff

\section{INTRODUCTION}

The climate change driven by anthropogenic greenhouse gas emission will alter the freshwater resources (IPCC 2014), which might adversely stress its availability and use (Gerten et al., 2013), and increase the risks associated with changes in runoff and stream flow (Hirabayashi et al 2008., 2013, Gosling and Arnell 2013, Arnell and Lloyd- Hughes 2014). Various general circulation model (GCM) experiments and studies indicate that a substantial rise in global temperature would be expected as a consequence of a doubling of carbon dioxide (CO2) concentrations. As a result, climatic processes are likely to intensify, including the severity of hydrological events such as droughts, flood waves, and heat waves. These projected effects of possible future climate change would significantly affect many hydrologic systems, which in turn affect the water availability and runoff and the flow in rivers. Hence, an assessment of the possible impacts of climate change on the hydrology of a basin is essential in the wake of global warming.

By simulating stream flow from precipitation and temperature data derived from GCM outputs corresponding to the specific climate change scenarios, using a suitable hydrological model is possible for one to quantify the corresponding changes in the hydrology of the basin. However, the projections of the estimates of these climate variables for a future period obtained directly from GCMs are of limited value for any study as the spatial resolution of GCM is too coarse to resolve many sub-grid scale hydrological processes and because the output is always unreliable at individual grid. Spatial downscaling methods have been proposed to solve this problem. The methods used to convert GCM outputs into local meteorological variables used for hydrological modelling are referred to as downscaling techniques (Dibike and Coulibaly, 2005; Xu et al., 2009).

The approaches employed to change GCM data to a finer scale could be broadly classified into two categories, statistical downscaling and dynamical downscaling (Tripathi et al., 2006). Statistical downscaling method establishes an empirical relationship between GCM climate variable and local climate (Karl, et al., 1990), whereas in dynamical downscaling Regional Climate Model (RCM) is embedded within a GCM. Dynamical downscaling techniques can be grouped 


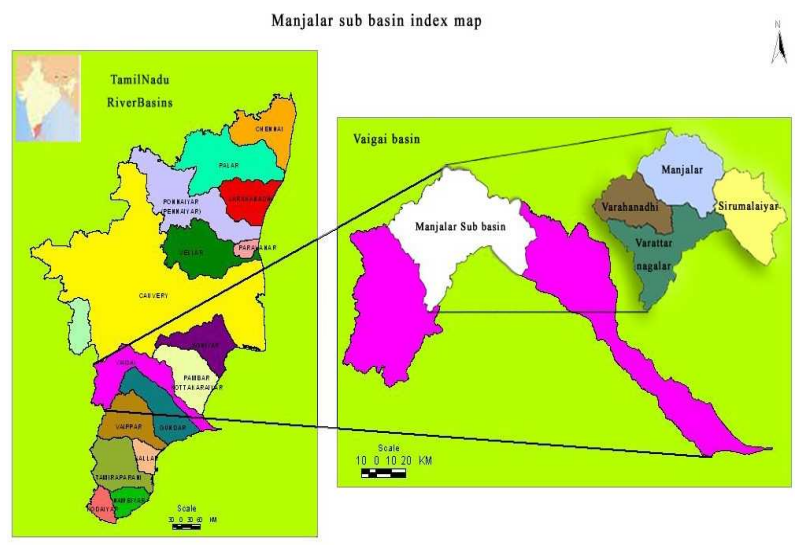

Fig.1. Location of study area.

into two classes such as high resolution and variable resolution atmospheric GCM (AGCM) and Regional climate models (RCMs). The main advantages of RCM include its ability to simulate high resolution information on a large physically consistent set of climate variables and its better representation of extreme events.

Future emissions and the future state of society are inherently unknowable, and are typically represented by suites of plausible scenarios. Many studies have used the IPCC's SRES scenarios (IPCC 2000) to characterise future emissions and socio-economic characteristics. The emissions trajectories in these scenarios were determined by the assumed socioeconomic conditions; the A2 socio-economic storyline is matched with an $\mathrm{A} 2$ emissions profile, and so on. However, such an approach does not readily allow an assessment of the relative importance of emissions trajectories (or the rate of climate change) versus socio -economic futures on the potential consequences of climate change. A new assessment methodology therefore adopts a 'matrix' approach, assessing impacts under different combinations of rate of change and socioeconomic futures (Moss et al. 2010). Under this approach, the rate of climate change is characterized

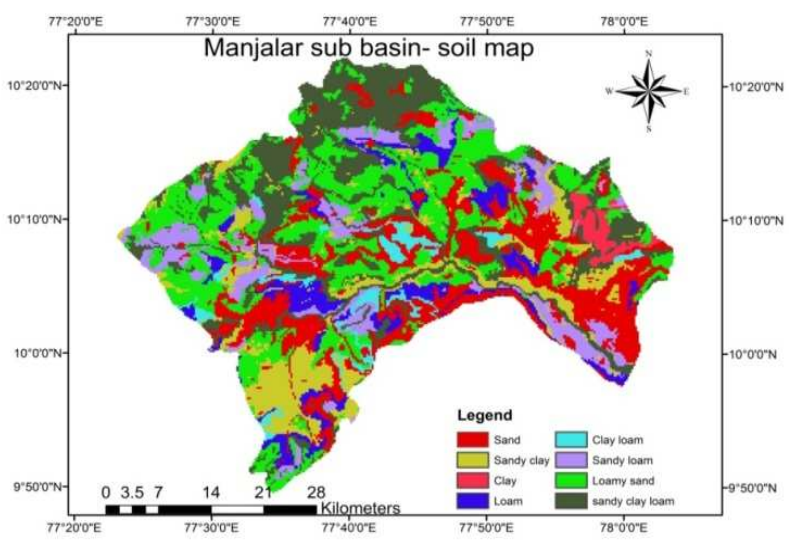

Fig.2. Soil map of Manjalar sub-basin.

by four Representative Concentration Pathways (RCPs) following: Moss et al., (2010) and van Vuuren et al. (2011a), defining different amounts of radiative forcing on the atmosphere. There are four RCP scenarios: RCP2.6, RCP4.5,RCP 6.0 and RCP8.5. These scenarios are formulated such that they represent the full range of stabilization, mitigation and baseline emission scenarios. The naming convention reflects socioeconomic pathways that reach a specific radiative forcing by the year 2100. For example, RCP8.5 leads to a radiative forcing of $8.5 \mathrm{Wm}^{-2}$ by 2100 .

The forecasts look at only two of the four scenarios, RCP 4.5 and RCP 8.5. The RCP 4.5 emissions scenario is a conservative/business-as-usual trajectory, while RCP 8.5 is a worst case emissions scenario. The Soil and Water Assessment Tool (SWAT) (Arnold et al., 1998) is a process-based continuous hydrological model that can predict the impact of land management practices spatio-temporally on water and agricultural yields in complex watersheds with varying soils, land use and management conditions.

The Vaigai basin is an important basin among the 12 basins lying between the Cauvery and Kanyakumari and it has fertile, lush green paddy fields and well

Table 1. Observed and SWAT simulated average monthly stream flow at different gauging stations of Manjalar sub-basin during calibration (1992-1995) and validation (1996-1998).

\begin{tabular}{|c|c|c|c|c|c|}
\hline Reservoirs & Aver: & flow (cfs) & PBIAS & NSE & $\mathbf{D}^{2}$ \\
\hline Calibration & Observed & Simulated & $(\%)$ & INSE & $\mathbf{K}$ \\
\hline Vaigai dam & 1926.25 & 1663.64 & -13.63 & 0.91 & 0.96 \\
\hline Manjalar dam & 1458.15 & 1230.3 & -15.63 & 0.97 & 0.97 \\
\hline Validation & Observed & Simulated & & & \\
\hline Vaigai dam & 6902.23 & 5965.33 & -13.58 & 0.96 & 0.99 \\
\hline Manjalar dam & 1837.53 & 1555.92 & -15.33 & 0.97 & 0.99 \\
\hline
\end{tabular}

Table 2. Annual changes expected in maximum and minimum temperature $\left({ }^{0} \mathrm{C}\right)$ in Manjalar sub- basin.

\begin{tabular}{|c|c|c|c|c|c|c|c|}
\hline \multicolumn{8}{|c|}{ Maximum temperature $\left({ }^{0} \mathrm{C}\right)$} \\
\hline \multicolumn{5}{|c|}{ RCP 4.5} & \multicolumn{3}{|c|}{ RCP 8.5} \\
\hline Seasons & $\mathrm{BL}$ & $\mathrm{NC}$ & $\mathrm{MC}$ & $\mathrm{EC}$ & $\mathrm{NC}$ & MC & $\mathrm{EC}$ \\
\hline Annual & 30.2 & 31.0 & 31.8 & 32.5 & 31.3 & 32.6 & 34.2 \\
\hline \multicolumn{8}{|c|}{ Minimum temperature $\left({ }^{0} \mathrm{C}\right)$} \\
\hline Annual & 18.1 & 18.8 & 19.7 & 20.3 & 19.1 & 20.5 & 22.2 \\
\hline
\end{tabular}




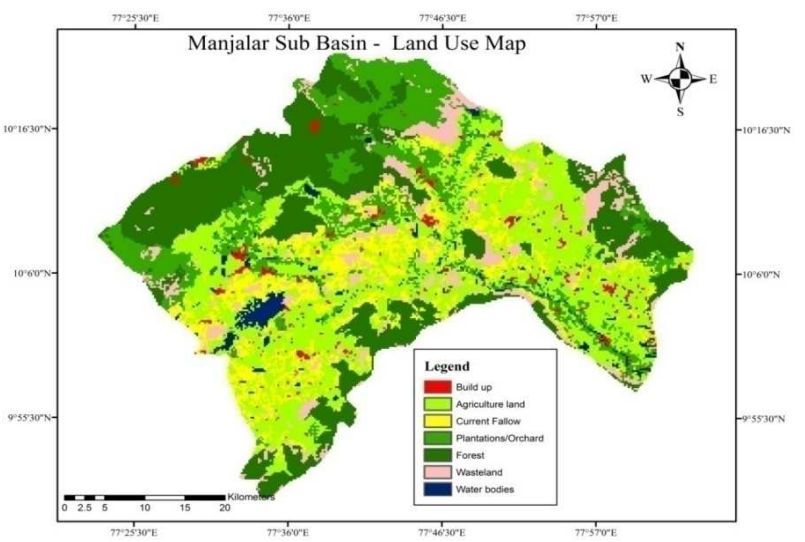

Fig. 3. Land use / Land Cover map of Manjalar sub-basin.

developed irrigation system. Next to Cauvery river basin, this basin can be considered as the granary of Southern Tamil Nadu. Manjalar sub-basin is the one of the important basin in Vaigai. The Manjalar sub basin is grouped into 4 sub basins such as Varattar Nagalar, Varahanadhi, Manjalar and Sirumalaiar sub basin and spread over an area of $2166 \mathrm{~km}^{2} .40 \%$ of the basin area $\left(873.3 \mathrm{~km}^{2}\right)$ is covered with hills and dense forest cover.

This paper presents an assessment of impacts of climate change on Manjalar sub basin exposure to changes in hydrology using the SWAT model. The hydrological model is validated for the baseline period with the downscaled output of GCMs. The assessment of impacts of climate change on the study area is carried out by incorporating the future rainfall and temperature data was downscaled using HadGEM2 model. The changes in simulated hydrology in the study area between current and future scenarios are investigated under two different combinations of rate of climate forcing (RCP4.5 and RCP 8.5) scenarios.

\section{MATERIALS AND METHODS}

Study area: The $2166 \mathrm{~km}^{2}$ Manjalar sub basin (Fig. 1), selected for this study, is a sub-basin of the

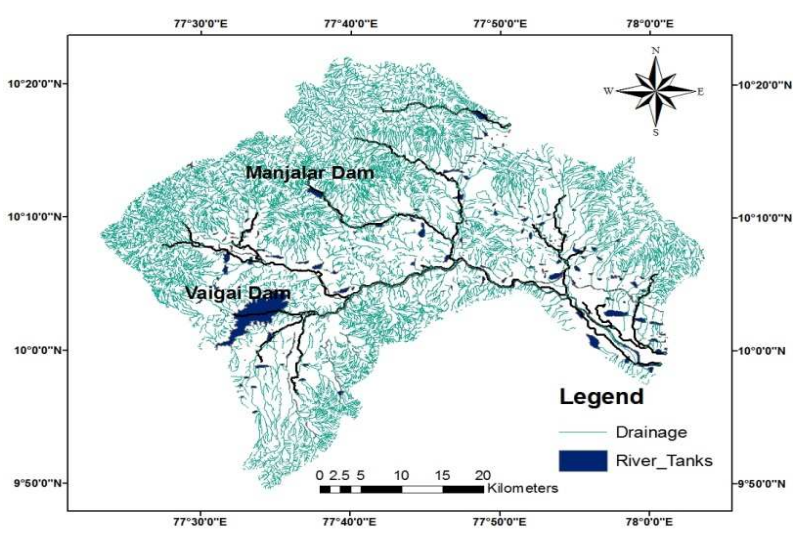

Fig. 4. Location Map of Vaigai and Manjalar Dam.

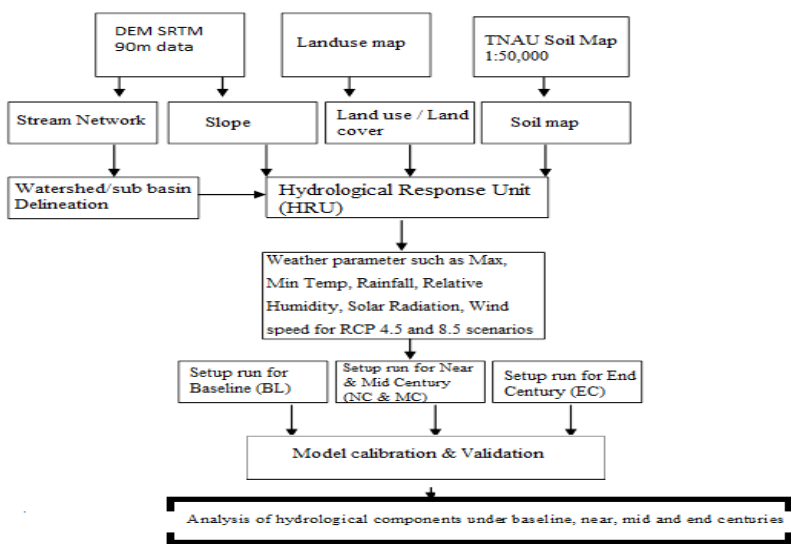

Fig. 5. Schematic diagram on the Input and Output files of SWAT model.

Vaigai basin in east coast of India in Tamil Nadu region from latitude $9^{\circ} 50^{\prime} \mathrm{N}$ to $10^{\circ} 20^{\prime} \mathrm{N}$ and $77^{\circ} 20^{\prime} \mathrm{E}$ to $78^{\circ} 10^{\prime} \mathrm{E}$ longitude. The sub basin, as determined using National Remote sensing Centre (NRSC) was comprised of $32.8 \%$ Agricultural land, $24.8 \%$ forest, $16.6 \%$ Plantation and orchard crops, $12.1 \%$ current fallows, $9.3 \%$ waste lands, $2.4 \%$ water bodies and 2.0 $\%$ urban area (Fig. 3). Manjalar sub- basin has a variety of soils (Fig 2); majority of the area is

Table 3. Changes in mean annual rainfall in Manjalar sub- basin for RCP 4.5 and RCP 8.5 scenarios.

\begin{tabular}{|c|c|c|c|c|c|c|c|}
\hline & \multicolumn{4}{|c|}{ RCP 4.5} & \multicolumn{3}{|c|}{ RCP 8.5 } \\
\hline & BL (mm) & $\mathrm{NC}(\mathrm{mm})$ & $\mathrm{MC}(\mathbf{m m})$ & EC (mm) & $\mathrm{NC}(\mathrm{mm})$ & $\mathrm{MC}(\mathbf{m m})$ & $\mathrm{EC}(\mathrm{mm})$ \\
\hline Basin 1 & 1124.7 & 1325.6 & 1385.6 & 1396.9 & 1354.1 & 1392.8 & 1470.3 \\
\hline Basin 2 & 1275.2 & 1402.4 & 1445.4 & 1477.1 & 1469.1 & 1479.1 & 1525.8 \\
\hline Basin3 & 945.1 & 951.4 & 967.4 & 977.4 & 974.2 & 974.9 & 988.5 \\
\hline Basin 4 & 601.5 & 630.7 & 672.2 & 696.8 & 685.5 & 692.2 & 702.3 \\
\hline Average & 986.6 & $\mathbf{1 0 7 7 . 5}$ & 1117.6 & 1137.1 & 1120.7 & 1134.7 & 1171.7 \\
\hline \multicolumn{8}{|c|}{$\%$ of deviation from baseline } \\
\hline Basin 1 & 17.9 & & 23.2 & 24.2 & 20.4 & 23.8 & 30.7 \\
\hline Basin 2 & 10.0 & & 13.3 & 15.8 & 15.2 & 16.0 & 19.6 \\
\hline Basin3 & 0.7 & & 2.4 & 3.4 & 3.1 & 3.1 & 4.6 \\
\hline Basin 4 & 4.9 & & 11.7 & 15.8 & 14.0 & 15.1 & 16.8 \\
\hline Average & 9.2 & & 13.3 & 15.2 & 13.6 & 15.0 & 18.8 \\
\hline
\end{tabular}

Note: BL- Base Line (1982-2012), NC-Near Century (2012-2039), MC-Mid Century (2040-2069), EC-End Century (2070-2098) 
Table 4. Comparison of Change in Land Use.

\begin{tabular}{|c|c|c|c|c|c|c|}
\hline \multirow{2}{*}{$\begin{array}{l}\text { S. } \\
\text { N. }\end{array}$} & \multicolumn{2}{|r|}{ Land use category } & \multirow{2}{*}{$\begin{array}{l}\text { Area in } \\
\text { Sq.Km As } \\
\text { on } 2001 \\
\end{array}$} & \multirow[b]{2}{*}{$\%$} & \multirow{2}{*}{$\begin{array}{c}\text { Area in } \\
\text { Sq.Km } \\
\text { As on } 2010 \\
\end{array}$} & \multirow[b]{2}{*}{$\%$} \\
\hline & I Level & II Level & & & & \\
\hline 1 & $\begin{array}{l}\text { Built up } \\
\text { land }\end{array}$ & Settlement & 43.33 & 2.00 & 68.89 & 3.18 \\
\hline 2 & Crop land & $\begin{array}{l}\text { Wet crop land-Paddy, Sugar cane and ba- } \\
\text { nana. } \\
\text { Dry crop land- Groundnut, ragi, cholam, } \\
\text { cumbu, maize, cereals, cotton, chilies, black } \\
\text { gram, red gram, vegetables, floriculture etc. }\end{array}$ & 710.59 & 32.80 & 615.48 & 28.41 \\
\hline 3 & Forest land & $\begin{array}{l}\text { Medium Dense forest } \\
\text { Dense forest and plantation } \\
\text { Hills covered by shrubs/ scrubs } \\
\text { Reserved Forest }\end{array}$ & 896.90 & 41.40 & 933.73 & 43.10 \\
\hline 4 & Waste land & $\begin{array}{l}\text { Barren land, Rocky out crop, stony waste } \\
\text { Area affected by alkalinity/salinity } \\
\text { Land covered by shrub/ scrub }\end{array}$ & 463.62 & 21.40 & 491.56 & 22.69 \\
\hline 5 & $\begin{array}{l}\text { Water bod- } \\
\text { ies }\end{array}$ & $\begin{array}{l}\text { Back swamp } \\
\text { Tanks } \\
\text { Reservoir }\end{array}$ & 51.99 & 2.40 & 56.76 & 2.62 \\
\hline To & l area & & 2166.43 & 100.00 & 2166.43 & 100.00 \\
\hline
\end{tabular}

dominated by loam $(60.1 \%)$ and sandy clay loam $(12.0 \%)$ soil. The soils in remaining areas are sand $(2.0 \%)$, sandy clay $(10.2 \%)$, clay $(0.3 \%)$, clay loam (4.1\%), sandy loam (3.5\%) and loamy sand (7.8\%) soil based on the soil texture using the pedo-transfer functions developed by Saxton and Rawls (2006). Elevation in the subbasin varies from 143 to $2410 \mathrm{~m}$. The study area is characterized by hot summers and mild winters with average temperatures of $29.5^{\circ} \mathrm{C}$ and $17.6^{\circ} \mathrm{C}$, respectively. The long term annual average rainfall in the watershed is $876.9 \mathrm{~mm}$. The mean annual precipitation varies from about $600 \mathrm{~mm}$ at the central and south western plain area to more than $1590.3 \mathrm{~mm}$ at the North western mountain areas. The survey of India Toposheets Nos. 58 F8, 58 F11, 58 F12, 58 F15, 58 F16, 58 G9, 58 G13, 58 J4 and 58 K1 cover the area. The major sub basins of this basin are Varattar - Nagalar, Varahanadhi, ManjalarMarudhanadhi and Sirumalaiar (Fig. 1). Data
Acquisition and Model (SWAT) used in the study.

Soil and water assessment tool (SWAT): was used to set up and develop models for the Manjalar sub basin. Data required in this study included Digital Elevation Model (DEM), soil properties, land use/cover, climate data such as precipitation, solar radiation, relative humidity, wind velocity and minimum/maximum temperature. A 90-m resolution DEM was used to delineate the watershed and sub-watershed boundaries, which were used in the model. A digital soil map (Fig 2) of Tamil Nadu at 1:50,000 scale obtained from Remote Sensing Unit of Tamil Nadu Agricultural University (TNAU) was used to define the soils of Tamil Nadu portion of the basin. The Land Use/Land Cover map (Fig 3) was obtained from the National Remote Sensing Centre (NRSC) for the year 2007. Daily precipitation minimum and maximum air temperature, solar radiation, relative humidity, and wind velocity data between January 1982 and December 2012 were

Table 5. Changes in mean annual Evapo transpiration (ET) in Manjalar sub- basin for RCP 4.5 and RCP 8.5 scenarios.

\begin{tabular}{lccccccc}
\hline & \multicolumn{2}{c}{ RCP 4.5 (in mm) } & \multicolumn{3}{c}{ RCP 8.5 (in mm) } \\
\hline & BL $(\mathrm{mm})$ & $\mathrm{NC}(\mathrm{mm})$ & $\mathrm{MC}(\mathrm{mm})$ & $\mathrm{EC}(\mathrm{mm})$ & $\mathrm{NC}(\mathrm{mm})$ & $\mathrm{MC}(\mathrm{mm})$ & $\mathrm{EC}(\mathrm{mm})$ \\
\hline Basin 1 & 213.1 & 214.5 & 228.1 & 231.3 & 235.2 & 244.3 & 246.2 \\
Basin 2 & 223.1 & 224.9 & 233.1 & 244.7 & 264.5 & 269.5 & 276.5 \\
Basin3 & 187.6 & 193.9 & 200.3 & 196.0 & 194.3 & 203.6 & 209.1 \\
Basin 4 & 155.3 & 158.3 & 161.0 & 164.2 & 169.1 & 171.5 & 175.5 \\
Average & 194.8 & 197.9 & 205.6 & 209.0 & 215.8 & 222.2 & 226.8 \\
\hline \% of deviation from baseline & 0.7 & & & & & 15.6 \\
\hline Basin 1 & 0.8 & 7.0 & 8.5 & 10.4 & 18.6 & 20.8 & 23.9 \\
Basin 2 & 3.4 & 4.5 & 9.7 & 18.6 & 11.5 \\
Basin3 & 1.9 & 6.8 & 4.5 & 3.6 & 8.6 & 13.0 \\
Basin 4 & 1.6 & 3.7 & 5.7 & 8.9 & 10.5 & 16.5 \\
Average & & 5.6 & 7.3 & 10.8 & 14.1 & \\
\hline
\end{tabular}


collected from Institute of Water Studies (IWS), Groundwater division, Public Works Department, Taramani, Chennai (Fig. 1). Flow data for the period from 1982 to 2000 were obtained from gauging stations of Vaigai dam and Manjalar dam which were located within the sub basin (Fig. 4).

Climate model and climate scenarios: Regional Climate Model (RCM) used for the study was RegCM 4.4rc 22 (Regional Climate Model version 4.4), which was free source obtained from International Centre for Theoretical Physics, Italy under Earth System Physics Section in this site:https://gforge.ictp.it/gf/project/regcm/ frs/? action=Frs ReleaseBrowse\&frs_package_id=31. For climate change study to run the RCM, Global Climate Model output of HadGEM2 was used under RCP 4.5 and 8.5 scenarios. The model was run for $0.22^{\circ} \times 0.22^{\circ}$ resolution. Daily data was obtained by means of shell script as output for six weather parameters viz., solar radiation $\left(\mathrm{MJ} / \mathrm{m}^{2}\right)$, maximum temperature $\left({ }^{\circ} \mathrm{C}\right)$, minimum temperature $\left({ }^{\circ} \mathrm{C}\right)$, rainfall $(\mathrm{mm})$, relative humidity $(\%)$ and wind speed $(\mathrm{Km} / \mathrm{h})$. The output was in 30 days calendar, so for the months with 31 days, average of $30^{\text {th }}$ of previous month and $1^{\text {st }}$ of succeeding month was taken. In case of February two days were removed for normal years, in case of leap year one day alone was removed. A total of 128 years of simulation has been conducted; 35 years each belonging to Base Line (BL: 1971-2011), Near Century (NC: 2012-2039), Mid Century (MC: 2040-2069) and End Century (EC: 2070 -2098) climate scenarios.

Flowchart for the impact of climate change on hydrology of Manjalar sub basin: The overall methodology for SWAT model and climate change impacts assessment is presented in the flowchart (Fig.5).

Calibration and validation of SWAT model: SWAT model was run from 1989 to 1998.The periods 19921995 and 1996-1998 were selected as the calibration and validation periods, respectively, for flow. The first four years (1989-1991) were used to minimize uncertain initial conditions. Model was first calibrated for stream flow using data from the gauge station. Quantitative measures Percent BIAS (PBIAS), Coefficient of determination $\left(\mathrm{R}^{2}\right)$ and Nash-Sutcliffe Efficiency (NSE) were also used during calibration

\section{RESULTS AND DISCUSSION}

Evaluation of hydrological model - SWAT model: Comparison between observed and SWAT simulated average monthly stream flow at different gauge stations in the Manjalar sub- basin (Table 1) revealed that the simulated stream flow matches well with the observed values. The $\mathrm{R}^{2}$ value is more than 0.90 during calibration and validation period for all the stream gauge stations which indicated good agreement between observed and simulated flows.

Percent BIAS (PBIAS) values for monthly stream flow during calibration and validation periods were found to be between -13.58 and $-15.63 \%$. This indicates that the SWAT model could be well used to predict the average monthly values of stream flow and the model simulation is good as the PBIAS is $< \pm 20$ per cent. Nash Sutcliffe Efficiency (NSE) gave very high values during the simulation period under calibration and validation (0.91 to 0.97) for the two control points indicating the good predictability of stream flow by the SWAT model. The coefficients of determination $\left(\mathrm{R}^{2}\right)$ values were also very high (0.96 to 0.99$)$ showing very close similarity between simulated and observed stream flow. Moriasi et al. (2007) found that the statistical measures (NSE, R ${ }^{2}$ ) for monthly stream flow are above 90 per cent indicating very high predictability of the model.

The $\mathrm{R}^{2}$ value for annual stream flow during calibration and validation period was more than 0.90 for the two reservoirs (Vaigai and Manjalar) indicating high degree of collinearity between simulated and observed data. Santhi et al. (2001) and Van Liew et al. (2003) observed that the stream flow during calibration and validation period was more than 0.90 , indicates that the values are high degree of collinearity.

Table 6. Changes in mean soil water storage in Manjalar sub- basin for RCP 4.5 and RCP 8.5 scenarios.

\begin{tabular}{lccccccc}
\hline & \multicolumn{3}{c}{ RCP 4.5 } & \multicolumn{3}{c}{ RCP 8.5 } \\
\hline & BL $(\mathrm{mm})$ & $\mathrm{NC}(\mathrm{mm})$ & $\mathrm{MC}(\mathrm{mm})$ & $\mathrm{EC}(\mathrm{mm})$ & $\mathrm{NC}(\mathrm{mm})$ & $\mathrm{MC}(\mathrm{mm})$ & $\mathrm{EC}(\mathrm{mm})$ \\
\hline Basin 1 & 544.5 & 567.0 & 573.9 & 575.4 & 546.8 & 515.3 & 520.4 \\
Basin 2 & 417.9 & 421.3 & 443.2 & 429.6 & 457.7 & 410.8 & 408.4 \\
Basin3 & 226.8 & 232.2 & 242.7 & 244.9 & 237.2 & 196.2 & 186.6 \\
Basin 4 & 108.2 & 116.7 & 117.3 & 117.5 & 110.0 & 85.8 & 74.4 \\
Average & 324.4 & 334.3 & 344.3 & 341.8 & 337.9 & 302.0 & 297.4 \\
\hline \% of deviation from baseline & & & & & -4 \\
\hline Basin 1 & 4.1 & 5.4 & 5.7 & 0.4 & -5.4 & -4.4 \\
Basin 2 & 0.8 & 6.1 & 2.8 & 9.5 & -1.7 & -2.3 \\
Basin3 & 2.4 & 7.0 & 8.0 & 4.6 & -13.5 & -17.7 \\
Basin 4 & 7.8 & 8.4 & 8.6 & 1.7 & -20.7 & -31.3 \\
Average & 3.1 & 6.1 & 5.4 & 4.2 & -6.9 & -8.3 \\
\hline
\end{tabular}


Changes in the maximum and minimum temperature due to climate change: The RCP 4.5 showed an increase of annual maximum temperature of $0.8^{\circ} \mathrm{C}$, $1.6^{\circ} \mathrm{C}$ and $2.3^{\circ} \mathrm{C}$ from baseline temperature of $30.2^{\circ} \mathrm{C}$ for near, mid and end centuries respectively (Table 2 ). Similarly, the RCP 8.5 showed still higher increase in temperature of $1.1^{\circ} \mathrm{C}, 2.4{ }^{\circ} \mathrm{C}$ and $4.0^{\circ} \mathrm{C}$ from baseline temperature of $30.2^{\circ} \mathrm{C}$ for near, mid and end centuries respectively. This model produces a warming trend in the end century under RCP 8.5; in contrast, RCP 4.5 predicts a lower average warming rate for near, mid and end century with the decreasing radiative forcing (Fengge et. al., 2013). Similar kind of increased projection for India was also observed by Rajiv kumar et al., (2012). A higher increase in minimum temperature was noticed both in RCP 4.5 and 8.5 scenarios. The scale of increase from baseline minimum temperature for RCP $4.5\left(0.7,1.6\right.$ and $\left.1.6^{\circ} \mathrm{C}\right)$ and RCP $8.5\left(1.0,2.4\right.$ and $\left.3.1^{\circ} \mathrm{C}\right)$ respectively from baseline temperature of $18.1^{\circ} \mathrm{C}$ for near, mid and end century. Rupakumar et al., (2006) also found that the maximum and minimum temperatures are also expected to increase into the future.

Changes in the annual rainfall due to climate change: The mean annual rainfall expected to increase is about $1117.6 \mathrm{~mm}(13.3 \%)$ in mid century and $1137.1 \mathrm{~mm}(15.3 \%)$ in the end century of RCP 4.5 scenario, whereas the same is expected to increase about $1134.7 \mathrm{~mm}(15.0 \%)$ in mid century and 1171.7 $\mathrm{mm}(18.8 \%)$ in the end century of RCP 8.5 scenario (Table 3) in the basin. The end century showed a significant increase in precipitation compared to mid century, near century and baseline for both scenarios. This result is in line with the findings of Rupa Kumar et al., (2003) which showed that, the increase of rainfall is likely to increase all over Tamil Nadu in the future years.

Rainfall projections among the four basins of Manjalar sub basin, Basin 1 has been likely to receive higher rainfall of 17.9 and 20.4 per cent in near century (2012 -2039), 23.2 and 23.8 per cent in the mid century
(2040-2069) and 24.2 and 30.7 percent in the end century (2070-2098) of RCP 4.5 and RCP 8.5 scenarios than other basins (basin 2, 3 and 4). It was found that the Basin 1 has been receiving more amount of rainfall followed by Basin 2, 4 and Basin 3 for both scenarios. The precipitation increase in the basin 1 and basin 2 might be because of dense forest cover (Fig 3), an increase in mean annual surface air temperature and high elevation in that area.

Increased greenhouse concentration $\left(\mathrm{CO}_{2}\right.$ concentration of RCP 8.5 is above 1300 ppm whereas RCP 4.5 is $650 \mathrm{ppm}$ ) leads to increased atmospheric moisture variability due to increased surface warming which also leads to accelerated hydrological cycle and increased regional precipitation variability among the basins ((Lambert et al., 2006; Stott et al., 2010). Because of the above reasons, the RCP 8.5 scenario receives more rainfall than RCP 4.5 scenario.

Climate change on land use: This study was taken up to assess and analyze the past and present changes of agricultural land use geographically over a period of one decade (2001 and 2010) using remote sensing and GIS technique. The results indicate that severe land use changes have occurred in agricultural, built up land, water bodies and waste land areas which have been experienced in the study area between 2001 and 2010. A comparative statement is shown in the Table 4. Total built up land observed in 2010 is around 68.89 sq. $\mathrm{km}$ i.e. $3.18 \%$ of the total basin area where as in 2001 the built up land constituted in the basin area was 43.33 Sq.km i.e. $2.0 \%$. So the built up land has increased three times due to increasing habitation and industrial growth.

The total extent of the crop land observed in 2010 satellite imagery is about 615.48 sq.km i.e. $28.41 \%$ of the total basin area whereas in 2001 this category occupies about 710.59 sq. $\mathrm{km}$ i.e. $32.80 \%$ of the total sub basin area. Reducing trend of agriculture activities is being observed for the past one decade. Almost 95.11 sq. $\mathrm{km}$ of cultivable lands i.e. $4.39 \%$ have been reduced during the past one decade is due to the vaga-

Table 7. Changes in mean surface runoff in Manjalar sub- basin for RCP 4.5 and RCP 8.5 scenarios.

\begin{tabular}{lccccccc}
\hline \multicolumn{7}{c}{ RCP 4.5 } & \multicolumn{3}{c}{ RCP 8.5 } \\
\hline Basin 1 & BL $(\mathrm{mm})$ & $\mathrm{NC}(\mathrm{mm})$ & $\mathrm{MC}(\mathrm{mm})$ & $\mathrm{EC}(\mathrm{mm})$ & $\mathrm{NC}(\mathrm{mm})$ & $\mathrm{MC}(\mathrm{mm})$ & $\mathrm{EC}(\mathrm{mm})$ \\
Basin 2 & 154.2 & 196.0 & 228.3 & 258.0 & 347.0 & 379.4 & 390.6 \\
Basin3 & 474.3 & 664.3 & 669.8 & 881.3 & 755.8 & 866.2 & 991.5 \\
Basin 4 & 145.3 & 187.0 & 190.5 & 193.4 & 221.0 & 282.3 & 292.2 \\
Average & 200.6 & 412.3 & 428.6 & 468.7 & 459.6 & 569.7 & 574.6 \\
\hline \% of deviation from baseline & 243.6 & 364.9 & 379.3 & 450.4 & 445.8 & 524.4 & 562.2 \\
\hline Basin 1 & 27.1 & & & & 146.0 & 153.3 \\
Basin 2 & 40.1 & 48.0 & 67.2 & 125.0 & 82.6 & 109.1 \\
Basin3 & 28.7 & 41.2 & 85.8 & 59.4 & 54.3 & 101.1 \\
Basin 4 & 105.6 & 31.1 & 33.1 & 52.1 & 184.1 & 186.5 \\
Average & 49.8 & 113.7 & 133.7 & 129.2 & 115.3 & 130.8 \\
\hline
\end{tabular}


ries of monsoon, water level depletion poor agriculture management practice, and industrial growth leads the farmers to leave their agriculture activities and switch over to some other occupation.

The total forest land is $933.70 \mathrm{Sq} . \mathrm{Km}$ in this basin in 2010 whereas it was $896.90 \mathrm{Sq} . \mathrm{Km}$ in 2001 . The forest land has increased 1.7 percent due to increasing awareness about afforestration among the peoples. The extent of waste land observed in 2001 was 463.62 Sq. $\mathrm{km}$ i.e. $21.40 \%$ of the total basin area whereas in 2010 the extent waste land further increased up to 491.56 Sq.km i.e. $22.69 \%$ of the total basin area. The total area of water bodies has increased 0.22 percent (2010) due to increasing rehabilitation of water bodies.

Hydrological response to climate change: The spatial and temporal effects on hydrological response to climate change in terms of ET, soil water storage, groundwater contribution to stream flow and surface runoff was estimated and analysed for baseline (current condition), near, mid and end centuries for RCP 4.5 and RCP 8.5 scenarios.

Climate change and Evapo-transpiration (ET): The projected mean annual evapo- transpiration (ET) is likely to increase by $1.6(194.8 \mathrm{~mm})$ to $7.3(209.0 \mathrm{~mm})$ percent in RCP 4.5 scenario, whereas the same also likely to increase by $10.8(215.8 \mathrm{~mm})$ to $16.5(226.8$ $\mathrm{mm}$ ) percent in RCP 8.5 scenario (Table 5). It was found that there is a gradual increase of mean annual ET in the near, mid and end centuries of both scenarios.

In the case of RCP 4.5 scenario, the ET is likely to increase in basin 2 (9.7 percent), followed by basin 1 (8.5 percent), basin 4 (5.7 percent) and basin 3 (4.5 percent) in the end century whereas there would be an increasing trend towards the end century of RCP 8.5 scenario.

In the Basin 2, annual ET expected to increase by 18.6 (264.5 $\mathrm{mm})$ percent in the near, $20.8(269.5 \mathrm{~mm})$ percent in the mid and $23.9(276.5 \mathrm{~mm})$ percent in the end century under RCP 8.5 scenario whereas Basin 1 is likely to increase by $10.4(235.2 \mathrm{~mm})$ percent in the near, $14.6(244.3 \mathrm{~mm})$ percent in the mid and 15.5
(246.2 $\mathrm{mm}$ ) percent in the end century followed by basin 4 and basin 3 is also likely to increase by 13.0 percent and 11.5 percent in the end century of RCP 8.5 scenario. When comparing the RCP4.5 and RCP 8.5, the rate of increase in ET is higher in RCP 8.5 scenario. Both the RCP4.5 and the RCP 8.5 scenarios increase average evapotranspiration at least 7.3 and 16.5 percent in the end century. Even though the rainfall in RCP8.5 scenario is expected to increase slightly, simultaneous increases in temperatures will result in greater evaporative losses, it would be drive annual changes in the evapotranspiration Gosain et al. (2011).

Climate change and soil water storage: The mean annual soil water storage (Table 6) projections over the basin indicate an increase in the near future by 3.1 per cent $(334.3 \mathrm{~mm})$, increase by 6.1 percent $(344.3$ $\mathrm{mm}$ ) in mid century and likely to increase by 5.4 percent $(341.8 \mathrm{~mm})$ in the end century of RCP 4.5 scenario. In RCP 8.5 scenario, indicate an increase in the near century by 4.2 percent $(337.9 \mathrm{~mm})$ and then there would be a decline in the mid and end centuries by 6.9 percent $(302.0 \mathrm{~mm})$ and 8.3 percent $(297.4 \mathrm{~mm})$ than baseline of $324.4 \mathrm{~mm}$.

In the mid century, the annual soil water storage would increase by $5.4 \%, 6.1 \%, 7.0 \%$ and $8.4 \%$ in basin 1 , basin 2 , basin 3 and basin 4 respectively of RCP 4.5 scenario. In end-century of RCP 4.5 , it is likely to increase by $5.7 \%, 2.8 \%, 8.0 \%$ and $8.6 \%$ in basin 1 , basin 2 , basin 3 and basin 4 respectively. The annual soil water storage of basin 1, 2, 3 and 4 was projected an increase in the near century (from 0.4 to 9.5 percent) and then there would be a decline in the mid (from 1.7 to 20.7 percent) and end (from 2.3 to 31.3 percent) centuries of RCP 8.5 scenario. The percentage reduction in soil water storage might be attributed to the increased temperature, urbanization, evapotranspiration and rainfall variability in that region which was in accordance with the finding of Martin et al., (2010).

In the basin 1, the annual soil water storage is expected to increase by $0.4 \%$ in the near century, decline by 5.4 $\%$ in the mid century and again decline by of $4.4 \%$ in

Table 8. Changes in stream flow contribution to ground water in Manjalar sub- basin for RCP 4.5 and RCP 8.5 scenarios.

\begin{tabular}{lccccccc}
\hline & \multicolumn{2}{c}{ RCP 4.5 } & \multicolumn{3}{c}{ RCP 8.5 } \\
\hline & $\mathrm{BL}(\mathrm{mm})$ & $\mathrm{NC}(\mathrm{mm})$ & $\mathrm{MC}(\mathrm{mm})$ & $\mathrm{EC}(\mathrm{mm})$ & $\mathrm{NC}(\mathrm{mm})$ & $\mathrm{MC}(\mathrm{mm})$ & $\mathrm{EC}(\mathrm{mm})$ \\
\hline Basin 1 & 245.6 & 246.8 & 255.5 & 264.6 & 255.1 & 168.6 & 152.4 \\
Basin 2 & 165.3 & 167.2 & 179.4 & 190.5 & 167.9 & 117.2 & 106.5 \\
Basin3 & 128.6 & 129.2 & 152.8 & 144.8 & 139.4 & 122.8 & 108.8 \\
Basin 4 & 115.6 & 119.4 & 128.8 & 146.2 & 127.5 & 102.0 & 96.2 \\
Average & 163.8 & 165.7 & 179.1 & 186.5 & 172.5 & 127.6 & 116.0 \\
\hline \% of deviation from baseline & 0.5 & & & & & -37.9 \\
\hline Basin 1 & 1.2 & 4.0 & 7.7 & 3.8 & -31.4 & -35.5 \\
Basin 2 & 0.5 & 8.5 & 15.3 & 1.6 & -29.1 & -15.4 \\
Basin3 & 3.3 & 18.8 & 12.6 & 8.4 & -4.5 & -16.8 \\
Basin 4 & 1.2 & 11.4 & 26.5 & 10.3 & -11.8 & -29.2 \\
Average & & 9.4 & 13.9 & 5.3 & -22.1 & \\
\hline
\end{tabular}


the end century compared to baseline $(544.5 \mathrm{~mm})$ under RCP 8.5. The increase is expected at basin 2 by 9.5 $\%$ in near, decline by $1.7 \%$ and again decline by $2.3 \%$ in near, mid and end century respectively under the same scenario. In the mid century, the annual soil water storage would decrease by $13.5 \%$ and $20.7 \%$ in basin 3 and basin 4 respectively. In end-century, it is expected to decrease by $17.7 \%$ and $31.3 \%$ in basin 3 and basin 4 under RCP 8.5 scenario.

The annual soil water storage is predicted to increase in near, mid century and end century of RCP 4.5 scenario whereas an increase in the near century and there would be a decline in the mid and again there would be a decreasing trend towards the end centuries of RCP 8.5 scenario.

In RCP 8.5 scenario, there would be an increasing temperature (from 1.1 to $4.0^{\circ} \mathrm{C}$ ), high evapotranspiration (ranges from 10.8 to 16.5 percent) and industrial growth trend towards end centuries lead to reduces soil water storage in that scenario. However the RCP 4.5 scenario is a stabilization scenario, it has been less temperature (from 0.8 to $2.3^{0} \mathrm{c}$ ), solar radiation $(4.5 \mathrm{~W} /$ $\mathrm{m} 2$ ) and evapotranspiration (from 1.6 to 7.3 percent) than RCP 8.5 scenario resulted to increased soil water storage is also in line with the findings of WGII AR5,report (2013).

High reduction has also been predicted in the basin 4 in the mid and end century than other basins under RCP 8.5 scenario. This might be due soil type (dominant soil is sand and holding capacity is low), urbanization (Table 4) and evapotranspiration (less agricultural/ forest area and increased wasteland) in that basin.

Climate change and surface runoff: The RCP4.5 scenario of surface runoff in the CMIP5 models, which has a baseline of $243.6 \mathrm{~mm}$, show an increase of 49.8 percent in near, 55.7 percent in mid and 84.9 percent in end century (Table 7). Alternatively, the RCP8.5 scenario predictions range from 83.0 percent to 130.8 percent in near, mid and end centuries respectively.

The annual surface runoff is expected to increase in near, mid century and end century under RCP 4.5 scenario. In the mid century, it would increase by $48.0 \%$, $41.2 \%, 31.1 \%$ and $113.7 \%$ in basin 1, basin 2, basin 3 and basin 4 respectively. In end-century, it is expected to increase by $97.2 \%, 85.8 \%, 33.1 \%$ and $133.7 \%$ in basin 1, basin 2, basin 3 and basin 4 respectively.

In the basin 1, the annual surface runoff is expected to increase by $125.0 \%$ in the near, by $146.0 \%$ in the mid and by $153.3 \%$ in the end century compared to baseline $(154.2 \mathrm{~mm})$ under RCP 8.5 . The increase is expected at basin 2 by $59.4 \%, 82.6 \%$ and $109.1 \%$ in near, mid and end century respectively under the same scenario. In the basin 3 and 4, it is expected to increase by $94.3 \%$ and $184.1 \%$ in the mid century, whereas the same is expected to increase by $101.1 \%$ and $186.5 \%$ in the end century of RCP 8.5 scenario.
Under RCP 4.5 and 8.5 scenarios, the surface runoff in the study area is projected to increase in all the basins owing to the projected increase of precipitation (IPCC, 2001a). In sub basin 4, annual surface runoff is expected to increase under RCP 4.5 (133.7\%) and RCP $8.5(186.5 \%)$ scenario in the end century. Comparing with other basins, basin 4 is likely to increase the surface runoff due to it has been less forest area but more waste land and built up lands owing to more runoff than other basins. Surface runoff occurs when precipitation does not completely permeate into the ground and excess water runs across the surface. Some of the main physical characteristics that affect runoff when considering the future effects of climate change are land use, vegetation, soil type, drainage area and drainage network patterns (USGS, 2014). Land use change can be particularly problematic as urbanization increases. From the Table 7, it has been concluded that most of the agricultural land have been reduced during the past one decade which was changed into built up areas. This built up areas lead to more runoff which is impervious surfaces such as roads, trails, buildings and parking lots prevent water from being absorbed into soil, allow large amounts to enter streams like high surface runoff.

Further urbanization and land use change in the Manjalar sub basin (Table 4) has been recorded increased runoff in all of the basins for RCP 4.5and RCP 8.5 scenarios.

Climate change and stream flow contribution to ground water: Changes in annual stream flow contribution to ground water (Table 8), in the near, mid and end century, the increase is expected to be higher in the RCP 4.5 (1.2 percent, 9.4 percent and 13.9 percent) scenario and there would be declining trend of RCP 8.5 scenario (22.1 percent and 29.2 percent) in the mid and end centuries. This might be due to increased temperature, reduced soil water storage, precipitation amounts, timings, intensity rates, soil characteristics and land use pattern of the basin was also observed by Kumar (2012).

Under RCP 8.5 scenario, the highest expected ground water flow is observed in basin $2(59.7 \%)$ and basin 3 $(38.5 \%)$ in the end century. The reduction of ground water flow is expected in basin $2(29.1 \%$ and $35.5 \%)$ and basin 1 (31.4\% and 37.9\%) in mid and end centuries. Change in ground water flow might reduction in evapotranspiration, soil and aquifer type, type of soil water storage and ground water abstractions (Aguilera and Murillo, 2009; Stoll et al., 2011; Liu, 2011; Taylor R. et al., 2013).

\section{Conclusion}

The present case study aimed to assess the impacts of climate change on the hydrology of the basin the climate variables obtained as output from a coarser 
resolution RCM, HadGEM2 model is then downscaled to obtain finer resolution inputs required by the hydrological model using SWAT. The HadGEM2 estimated maximum and minimum temperatures were very close to Climate Research Unit (CRU) observations. The simulation model (HadGEM2) showed a high variability in their estimation of rainfall compared to the temperatures. SWAT model evaluation, Percent BIAS (PBIAS) values for monthly stream flow during calibration and validation periods were within the range limits and showing very close similarity between simulated and observed stream flow.

Annual maximum temperature, RCP 4.5 showed an increase of $0.8^{\circ} \mathrm{C}, 1.6^{\circ} \mathrm{C}$ and $2.3^{\circ} \mathrm{C}$ from baseline temperature of $30.2^{\circ} \mathrm{C}$ for near, mid and end centuries respectively. Similarly, the RCP 8.5 showed still higher increase in temperature of $1.1^{\circ} \mathrm{C}, 2.4{ }^{\circ} \mathrm{C}$ and $4.0^{\circ} \mathrm{C}$ from baseline temperature of $30.2^{\circ} \mathrm{C}$ for near, mid and end centuries respectively. The minimum temperature will increase by $0.7^{\circ} \mathrm{C}, 1.6^{\circ} \mathrm{C}$ and $1.6^{\circ} \mathrm{C}$ for near, mid and end century respectively from baseline temperature of $18.1^{\circ} \mathrm{C}$ for RCP 4.5 and $1.0^{\circ} \mathrm{C}, 2.4^{\circ} \mathrm{C}$ and $3.1^{\circ} \mathrm{C}$ for near, mid and end century for RCP 8.5 scenario. An increase of annual rainfall is expected to be $9.2 \%, 13.3 \%$ and $15.3 \%$ than the current quantity in near, mid and end centuries (RCP 4.5 scenario) respectively. In the RCP 8.5 scenario, the precipitation would be higher by $13.6 \%, 15.0 \%$ and $18.8 \%$ for mid, near and end centuries respectively.

In the Manjalar sub basin, the annual Evapotranspiration (ET) is expected to vary between 0.7 to 9.7 per cent under RCP 4.5 scenario and 3.6 to 23.9 per cent for RCP 8.5 scenario from current to end of $21^{\text {st }}$ centuries. The annual soil water storage is expected to vary between 0.8 to 8.6 per cent under RCP 4.5 scenario and -31.3 to +9.5 per cent for RCP 8.5 scenario from current to end of 21 st centuries. The annual Surface runoff is expected to increase between 27.1 to 133.7 per cent under RCP 4.5 scenario and 52.1 to 186.5 per cent for RCP 8.5 scenario from current to end of 21 st centuries. The annual stream flow contribution to ground water is projected to vary between 0.5 to 26.5 per cent under RCP 4.5 scenario and -37.9 to +10.3 per cent for RCP 8.5 scenario from current to end of 21 st centuries.

The possible changes projected by the study provide a useful input to effective planning of water resources of the study area. The study is intended to cater to the research on climate impact studies in developing countries, using freely available and less data-intensive models. In short, the study aimed at creating awareness, as to how the possible climate change can affect the water resources at local level and the need for modifying the existing water infrastructure in the region to sustain the water resources systems against future climate change.

\section{REFERENCES}

Aguilera,H and Murillo,J.M. (2009). The effect of possible climate change on natural groundwater recharge based on a simple model: a study of four karstic aquifers in SE Spain. Environmental Geology, 57(5): 963-974.

Arnell, N and Lloyd-Hughes B. (2014). The global-scale impacts of climate change on water resources and flooding under new climate and socio-economic scenarios. Climate Change 122 :127-40.

Arnold,J.G., Srinivasan, R., Muttiah ,R.S. and. Williams, J. R. (1998). Large area hydrologic modeling and assessment Part I: Model development. Journal of the American Water Resources Association, 34(1): 73-89.

Dibike, Y.B. and Coulibaly P. (2005). Hydrologic impact of climate change in the Saguenay watershed: comparison of downscaling methods and hydrologic models. Journal of Hydrology 307(1-4): 145-163.

Fengge Su, Xiaolan Duan, Deliang Chen, Zhenchun Hao and Lan Cuo. (2013). Evaluation of the Global Climate Models in the CMIP5 over the Tibetan Plateau. Journal of Climate, 26: 3187-3208.

Gerten D, Lucht W, Ostberg S, Heinke J, Kowarsch M, Kreft $\mathrm{H}$, Wkundzewicz Z, Rastgooy J, Warren $\mathrm{R}$ and Schellnhuber H J. (2013). Asynchronous exposure to global warming: freshwater resources and terrestrial ecosystems. Environmental Research Letter $8: 034032$.

Gosain, A. K., Sandhya Rao and Anamika Arora. (2011). Climate change impact assessment of water resources of India. Current Science 101(3): 356-371.

Gosling S and Arnell N (2013). A global assessment of the impact of climate change on water scarcity. Climate Change: $1-15$

Hirabayashi Y, Mahendran R, Koirala S, Konoshima L, Yamazaki D, Watanabe $\mathrm{S}$, Kim $\mathrm{H}$ and Kanae $\mathrm{S}$. (2013).Global flood risk under climate change. Nature Climate Change 3: 816-21.

IPCC (2014) Climate Change: Impacts, Adaptation, and Vulnerability. Contribution of Working Group II to the Fifth Assessment Report of the Intergovernmental Panel on Climate Change (Cambridge: Cambridge University Press)

IPCC. (2000). Emission scenarios. In: A special report of IPCC Working Group III, Cambridge University Press, Cambridge, UK.

Karl, T.R., Wang, W.C., Schlesinger, M.E., Knight, R.W. and Portman, D.(1990). A method of relating general circulation model simulated climate to observed local climate. Part I: Seasonal statistics. Journal of Climate. 3, 1053-1079.

Kumar, C. P. (2012). Climate Change and Its Impact on Groundwater Resources. International Journal of Engineering and Science Vol. 1, Issue 5, PP 43-60.

Lampert, R. J., Groves, D. G, Popper S. W and Bankes. S. C. (2006). A general, analytic method for generating robust strategies and narrative scenarios. Management Science, 52(4) : 514-528

Liu, H. (2011). Impact of climate change on groundwater recharge in dry areas: An ecohydrology approach. Journal of Hydrology, 407(1-4): 175-183.

Martin Jung, Markus Reichstein, Philippe Ciais and Sonia I. (2010). Seneviratne Recent decline in the global land evapotranspiration trend due to limited moisture supply. 
Nature (467): 951-954.

Moriasi, D. N, Arnold, J. G, Van Liew, M. W, Bingner, R. L, Harmel R. D. and Veith T. L..(2007). Model evaluation guidelines for systematic quantification of accuracy in watershed simulations. Transactions of the American Society of Agricultural Engineer 50(3): 885-900.

Moss, R. H., Edmonds J. A and Hibbard K. A. (2010). The next generation of scenarios for climate change research and assessment. Nature, 463: 747-756.

Rajiv Kumar,C., Joshi, J, Jayaraman M, Bala G and Ravindranath. N. H. (2012). Multi-model climate change projections for India under representative concentration Pathways. Current. Science. 103: 791-802.

Rupakumar, K.,. Sahai, A. K, Krishna Kumar, K., Patwardhan, S. K., Mishra, P. K., Revadekar, J. V., Kamala K. and G. B. Pant. (2006). High-resolution climate change scenarios for India for the 21 st century. Current Science, 90: 334-345.

Rupakumar, K., K. Kumar, V. Prasanna, K. Kamala, N. R. Desphnade, S. K. Patwardhan and G.B. Pant. (2003). Future climate scenario. In: Climate Change and Indian Vulnerability Assessment and Adaptation. Universities Press (India) Pvt. Ltd, Hyderabad. 462pp.

Santhi, C., J. G. Arnold, J. R. Williams, W. A. Dugas, R. Srinivasan and L. M. Hauck. (2001). Validation of the SWAT model on a large river basin with point and nonpoint sources. J. American Water Resources Association, 37(5): 1169-1188.

Saxton, K. E. and W. J. Rawls. (2006). Soil water characteristic estimates by Texture and organic matter for hydrologic solutions. Soil Science Society of America Journal, 70: 1569-1578.

Stoll, S., H. J. H. Franssen, R. Barthel and W. Kinzelbach. (2011). What can we learn from long-term groundwater data to improve climate change impact studies. Hydrology and Earth System Sciences, 15(12): 3861-3875.
Stott, P. A., N. P. Gillett, G. C. Hegerl, D. J. Karoly, D. A. Stone, X. Zhang and F. Zwiers. (2010). Detection and attribution of climate change: a regional perspective. Wiley Interdisciplinary Reviews-Climate Change, 1(2): 192-211.

Taylor, R. G., B. Scanlon, P. Döll, M. Rodell, R. van Beek, Y. Wada, L. Longuevergne, M. Leblanc, J. S. Famiglietti, M. Edmunds, L. Konikow, T. R. Green, J. Chen, M. Taniguchi, M. F. P. Bierkens, A. MacDonald, Y. Fan, R. M. Maxwell, Y. Yechieli, J. J. Gurdak, D. M. Allen, M. Shamsudduha, K. Hiscock, P. J. F. Yeh, I. Holman and H. Treidel. (2013). Ground water and climate change. Nature Climate Change, 3(4): 322-329.

Tripathi, S., Srinivas, V.V., and Nanjundiah, R. S. (2006). Downscaling of precipitation for climate change scenarios: A support vector machine approach. Journal of Hydrology. 330, 621-640.

USGS. (2014). Why Is This House Wearing Stilts? Retrieved from Impervious Surfaces and Urban Flooding: USGS Water-Science School: http://water.usgs.gov/edu/ impervious.html

Van Liew, M. W and J. Garbrecht. 2003. Hydrologic simulation of the Little Washita River experimental watershed using SWAT. Journal of American Water Resource. Association 39(2): 413-426.

Van Vuuren DP, Stehfest E, Den Elzen MGJ, Deetman S, Hof A, Isaac M, Klein Goldewijk K, Kram T, Mendoza Beltran A, Oostenrijk R .(2011a). RCP2.6: Exploring the possibility to keep global mean temperature change below $2^{\circ}$ C. Climatic Change. doi: 10.1007/s10584-0110152-3

Xu ZX, Zhao FF, Li JY. (2009). Response of streamflow to climate change in the headwater catchment of the Yellow River basin. Quaternary International 208: 62-75. 